\title{
Kecenderungan Narsistik Ditinjau Dari Kesepian Pada Mahasiswi Pengguna Jejaring Sosial Media Instagram Fakultas Ekonomi Universitas Prima Indonesia
}

\author{
Fani Natasya, Vion, Susi Anjelika, Heryanto. \\ Universitas Prima Indonesia, Medan, Indonesia \\ Email: sonialuo999@gmail.com
}

\begin{abstract}
This study aims to determine the relationship between lonely with narcissistic tendencies. The hypothesis of this study states that there is a negative relationship between lonely with narcissistic tendencies, assuming that the higher the lonely is, the lower the narcissistic tendencies, and conversely the lower the lonely is, the higher the narcissistic tendencies will be. The subjects of this study were 256 college students of Universitas Prima Indonesia. Datas were obtained from scales used to measure turnover intention and work stress. Calculations were performed by testing the analysis requirements (assumption) that consisted of tests for normality and linearity. The data were analyzed using Product Moment Correlation with SPSS 20 for Windows. The results of the data analysis showed that the correlation coefficient was 0,414 with a significance value of 0.000 ( $p<0.05$ ). It showed that there is a negative relationship between lonely and narcissistic tendencies. The results of this study indicate that the contributions made by the variable of work stress on turnover intention was 17,2 percent, while the remaining 82,8 percent was influenced by other factors that were not examined. From these results, it is concluded that the hypothesis, which stated that there is a negative relationship between the lonely and narcissistic tendencies, is acceptable.
\end{abstract}

Keywords : Narcissistic Tendencies, Lonely

\begin{abstract}
ABSTRAK
Penelitian ini bertujuan untuk mengetahui hubungan antara kesepian dengan kecenderungan narsistik. Hipotesis yang diajukan dalam penelitian ini adalah ada hubungan negatif antara kesepian dengan kecenderungan narsistik, dengan asumsi semakin tinggi kesepian, maka semakin rendah kecenderungan narsistik dan sebaliknya semakin rendah kesepian, maka semakin tinggi kecenderungan narsistik. Subjek penelitian yang digunakan dalam penelitian ini Mahasiswa Universitas Prima Indonesia berjumlah 130 orang. Data diperoleh dari skala untuk mengukur kecenderungan narsistik dan kesepian. Perhitungan dilakukan dengan melakukan uji prasyarat analisis (ujiasumsi) yang terdiri dari uji normalitas dan uji linearitas. Analisis data yang digunakan adalah menggunakan korelasi Product Moment (Pearson Correlation) dengan bantuan SPSS 20 for Windows. Hasil analisis data menunjukkan koefisien korelasi sebesar - 0,414 dan nilai signifikansi sebesar 0,000 ( $\mathrm{p}<0,05)$. Hasil analisis data tersebut menunjukkan adanya hubungan negatif antara kesepian dengan kecenderungan narsistik. Hasil penelitian ini menunjukkan bahwa sumbangan yang diberikan variabel kesepian terhadap kecenderungan narsistik sebesar 17,2 persen, selebihnya 82,8 persen dipengaruhi oleh faktor lain yang tidak diteliti. Dari hasil penelitian ini dapat ditarik kesimpulan bahwa hipotesis penelitian ada hubungan negatif antara kesepian dengan kecenderungan narsistik dapat diterima.
\end{abstract}

Kata Kunci : Kecenderungan Narsistik, Kesepian

\section{Pendahuluan}

Internet merupakan dunia baru yang penuh pesona. Dengan adanya internet akan dapat membentuk pola hubungan sosial baru di masyarakat melalui media-media sosial. Salah satu aplikasi media sosial yang paling banyak dikunjungi khususnya dikalangan mahasiswa adalah instagram. Pada akhirnya, penggunaan internet khususnya pada remaja hanya untuk keperluan jejaring sosial semata sebagai wadah memperluas hubungan sosialnya dalam jarak dekat maupun jarak jauh (Maulana \& Gumelar, 2013). Beberapa orang yang sering menggunakan jejaring sosial hanya untuk memamerkan kelebihan yang ia miliki. Dengan instagram, mereka dapat dengan mudah menggunggah foto atau video dengan tujuan ingin diperhatikan, ingin dipedulikan dan berharap orang lain akan mengapresiasi dengan memberi like dan komentar pada unggahan tersebut.

Novi (2017) melakukan penelitian terhadap mahasiswa PGSD UN PGRI Kediri dan menemukan beberapa fakta bahwa jumlah teman dalam akun Facebook sangat berhubungan dengan tingkat kepercayaan diri. Semakin banyak mereka memiliki teman maka semakin meningkat narsisme mereka di kehidupan nyata. Seperti kasus yang terjadi pada seorang remaja yang memamerkan fotofoto kekayaan yang ia miliki seperti tidur-tiduran dengan tumpukan uang ribuan dolar, membuang uang sebanyak $\$ 4000$, memamerkan tas-tas branded dengan status "orang bekerja sampai siang,

Diterima Redaksi : 07-05-2020 | Selesai Revisi : 12-06-2020 | Diterbitkan Online : 12-06-2020 
namun hanya mendapatkan separuh dari harga tas ini" (Vemale.com, 2013). Dapat diketahui bahwa remaja tersebut ingin menunjukkan sifat keakuan diri, memiliki kebutuhan untuk di kagumi dan merasa bahwa dirinya adalah individu yang istimewa.

Atas hasil wawancara yang dilaksanakan kepada mahasiswa Fakultas Ekonomi Universitas Prima Indonesia, peneliti mendapatkan berbagai informasi bahwa mahasiswa sering mengambil foto selfie yang kemudian akan di upload ke jejaring sosial. Setelah mereka selesai menggugah foto tersebut mereka merasa menjadi seseorang yang keren, up to date dengan lingkungan sekitar mereka. Hal tersebut mengacu kepada kecenderungan narsistik. Barlow dan Durand (2007) menyatakan bahwa individu dengan kecenderungan narsis memanfaatkan individu lain untuk kepentingan diri sendiri dan hanya menunjukkan sedikit empati kepada individu lain (Kartono, 2012). Individu dikatakan cenderung narsistik ketika seseorang tersebut cenderung pamer akan kelebihan-kelebihannya dengan menceritakan hal-hal mengenai dirinya sendiri pada akunnya dan enggan berbagi tips-tips bahkan ketika orang lain meminta bantuan.

Dian (2017) melakukan penelitian terhadap kecenderungan narsistik dan salah satu faktor yang mempengaruhi kecenderungan narsistik adalah kesepian. Hasil penelitian menemukan bahwa adanya hubungan negatif antara kesepian dengan narsisme, sehingga semakin kesepian pengguna instagram, maka semakin tidak narsisme, ini berarti semakin tinggi kesepian pada pelaku selfie di media sosial maka semakin rendah ciri-ciri narsistik pada pelaku selfie tersebut. Sebaliknya, semakin rendah kesepian pada pelaku selfie di media sosial maka semakin tinggi ciri-ciri narsistik pada pelaku selfie tersebut.

Kesepian didefinisikan sebagai suatu keadaan mental dan emosiaonal yang terutama dicirikan oleh adanya perasaan-perasaan terasing dan kurangnya hubungan yang bermakna dengan orang lain (Bruno, 2000). Orang yang kesepian akan lebih mudah berganti-ganti teman karena tidak mampu menjalin hubungan yang lebih baik dengan bersikap selalu menampakkan kelebihan diri agar menjadi pusat perhatian. Hal ini menjukkan bahwa perasaan kesepian yang dirasakannya semakin menarik dirinya untuk melakukan sikap narsistik. Russell (1996) mengatakan individu kesepian karena individu tidak mendapatkan kehidupan sosial yang diinginkan pada kehidupan di lingkungannya. Kesepian juga dapat menyerang individu setiap saat, tanpa memilih tempat atau keadaan sehingga dapat menarik dirinya untuk melakukan sikap narsistik. Penelitian menyimpulkan bahwa semakin tinggi kadar kesepian yang dirasakan seseorang, maka perilaku narsistik semakin rendah, atau sebaliknya semakin rendah kadar kesepian yang dirasakan seseorang, maka perilaku narsistik semakin tinggi.

\section{Metode Penelitian}

Adapun penelitian ini menggunakan metode skala. Skala yang digunakan dalam penelitian ini yaitu skala likert. Skala likert disajikan dalam bentuk pernyataan yang bersifat favourable dan unfavourable dengan empat alternative jawaban untuk setiap pertanyaan, yaitu SS (sangat sesuai), S (sesuai), TS (tidak sesuai), dan STS (sangat tidak sesuai).

Variabel yang terlibat pada penelitian ini berupa kesepian selaku variabel bebas dan kecenderungan narsistik selaku variabel tergantung. Sampel yang diambil pada penelitian ini ialah Mahasiswi semester 1,2,3 Fakultas Ekonomi di Universitas Prima Indonesia, Medan. Jumlah sampel yang diambil menggunakan ketentuan Isaac dan Michael (dalam Sugiyono, 2011) dari populasi sebanyak 1000 orang dengan perhitungan taraf kesalahan 5\% adalah minimal sebanyak 258 subjek. Pengumpulan sampel dalam penelitian ini memanfaatkan teknik purposive sampling. Metode pengambilan data menggunakan metode pembagian skala pengukuran kecenderungan narsistik dan kesepian. Instrumen yang dipakai pada penelitian merupakan skala Likert. Skala perilaku kecenderungan narsistik yang digunakan pada penelitian dirangkai bersumber pada karakteristik dari kecenderungan narsistik yang dikemukakan oleh Emmons (1995) di antaranya : Leadership (autority), Superiority (arogance Self absorption (self admiration), dan Exploitiveness (entitlement). Sedangkan skala kesepian yang digunakan didalam penelitian ini disusun berdasarkan aspek kesepian yang dikemukakan oleh Weiss (dalam Santrock, 2003) di antaranya : Isolasi emosional (emotional isolation) dan Isolasi sosial (social isolation). Hasil penelitian dianalisis menggunakan teknik korelasi Product Moment Pearson. 


\section{Hasil Dan Pembahasan}

Penelitian dilakukan pada tanggal 10 Januari 2020 pada 130 mahasiswi semester 1, 2 dan 3 Fakultas Ekonomi Universitas Prima Indonesia Medan. Pengambilan data dimulai dengan membagikan skala penelitian berupa skala kecenderungan narsistik yang terdiri dari 33 aitem dan skala kesepian yang terdiri dari 31 aitem. Adapun skala yang telah disusun kembali untuk penelitian ini dapat dilihat pada tabel 1 dan 2

Tabel 1. Penomoran Baru Skala Kecenderungan Narsistik Setelah Uji Coba Butir-butir Pernyataan

\begin{tabular}{ccccc} 
No. & Aspek Kecenderungan & Jumlah \\
\cline { 3 - 4 } & Narsistik & Favourable & Unfavourable & \\
\hline 1. & Leardership (authority) & $2,4,19,27$ & $7,930,33$ & $\mathbf{8}$ \\
\hline 2. & Superiority (arrogance) & $1,3,5,8,20$ & $10,25,26$ & $\mathbf{8}$ \\
\hline 3. & Self Absorption (self admiration) & $11,6,16,22,31$ & $12,15,21,32$ & $\mathbf{9}$ \\
\hline 4. & Exploitiveness (entitlement) & $13,14,23,29$ & $17,18,24,28$ & $\mathbf{8}$ \\
\hline & Total & $\mathbf{1 8}$ & $\mathbf{1 5}$ & $\mathbf{3 1}$
\end{tabular}

\begin{tabular}{|c|c|c|c|c|}
\hline \multirow[t]{2}{*}{ No. } & \multirow[t]{2}{*}{ Aspek Kesepian } & \multicolumn{2}{|c|}{ Butir-butir Pernyataan } & \multirow[t]{2}{*}{ Jumlah } \\
\hline & & Favourable & Unfavourable & \\
\hline 1. & $\begin{array}{l}\text { Isolasi Emosional (emotional } \\
\text { isolation ) }\end{array}$ & $2,8,9,10,26,27,28$ & $4,11,12,13,14,15,29$ & 15 \\
\hline 2. & $\begin{array}{c}\text { Isolasi Sosial } \\
\text { ( social isolation ) }\end{array}$ & $1,3,5,6,7,16,17,18,19$ & $20,21,22,23,24,25,31$ & 16 \\
\hline & Total & 16 & 15 & 31 \\
\hline
\end{tabular}

Berdasarkan tabel tersebut, maka jumlah seluruh aitem yang akan digunakan dalam penelitian adalah berjumlah 64 aitem. Langkah pertama untuk memudahkan pelaksanaan penelitian, skala prokrastinasi akademik dan skala perilaku menyontek digabung dalam satu set eksemplar, yang termasuk di dalamnya adalah (1) petunjuk pengisian skala, (2) identitas subjek, (3) skala kecenderungan narsistik, (4) skala kesepian. Langkah kedua adalah memberikan nilai dari setiap aitem dalam skala. Pemberian nilai dilakukan dengan melihat kembali bobot dari setiap aitem dan kemudian memasukkan data dengan bantuan Microsoft Excel yang kemudian akan disalin ke SPSS untuk dilakukan analisis data untuk mengetahui hubungan antara kedua variabel. Berdasarkan hasil dari SPSS 20.00 for windows, penelitian pada mahasiswi semester 1, 2 dan 3 di Fakultas Ekonomi Universitas Prima Indonesia Medan menunjukkan bahwa rata-rata (mean) untuk variabel kecenderungan narrsistik adalah sebesar 97.64 dengan SD (Standar deviasi) 21.628. Data yang dihasilkan menunjukkan bahwa 19 subjek (14.6\%) memiliki tingkat kecenderungan narsistik yang rendah, 45 subjek (34.6\%) dalam tingkat sedang, dan 66 subjek (50.8\%) berada dalam tingkat kecenderungan narsistik tinggi. Sedangkan hasil yang didapatkan pada rata-rata (mean) variabel kesepian berupa 83.49 dan SD (Standar Deviasi) 22.201. Terdapat 25 subjek $(19,2 \%)$ berada dalam tingkat kesepian rendah, 54 subjek $(41,6 \%)$ memiliki tingkat kesepian sedang, dan sebanyak 51 subjek $(39,2 \%)$ berada dalam tingkat kesepian tinggi. Berdasarkan hasil pengamatan dan wawancara keadaan Universitas Prima Indonesia Medan, Mahasiswi - Mahasiswi semester awal merasa kesepian dimana mereka belum beradaptasi dengan lingkungan baru dan kurang pandai dalam bergaul. Apalagi kondisi beberapa siswi yang dari luar kota dan tidak mempunyai kenalan. Rasa kesepian yang mereka rasakan tidak membuat mereka narsis melainkan sebaliknya. Beberapa yang mudah berteman dan sudah memiliki perkumpulan mereka lebih narsis dan suka memposting di sosial media. 
Teori-teori dan hasil-hasil penelitian dari para ahli di atas yang mengaitkan antara kesepian dan kecenderungan narsistik sejalan dengan hasil penelitian yang telah dilakukan, yaitu semakin tinggi kadar kesepian yang dirasakan seseorang, maka perilaku narsistik semakin rendah, atau sebaliknya semakin rendah kadar kesepian yang dirasakan seseorang, maka perilaku narsistik semakin tinggi

Tabel 3. Hasil Uji Normalitas

\begin{tabular}{cccccc}
\hline Variabel & SD & KS-Z & Sig & P & Ket \\
\hline Kecenderungan Narsistik & 8.660 & 0.991 & 0.14 & $\mathrm{p}>0.05$ & Sebaran normal \\
\hline Kesepian & 10.758 & 1.055 & 0.108 & $\mathrm{p}>0.05$ & Sebaran normal \\
\hline
\end{tabular}

Uji normalitas yang digunakan berupa Kolmogorov Smirnov test. Hasil menunjukkan data memiliki sebaran normal jika p>0,05 (Priyatno, 2011). Uji normalitas pada kecenderungan narsistik memperoleh hasil signifikansi uji satu arah yaitu 0.14 ( $p>0.05)$, bermakna bahwa data dalam variabel kecenderungan narsistik berdistribusi dan mempunyai sebaran normal. Untuk variabel kesepian diperoleh hasil signifikansi 0.108 ( $\mathrm{p}>0.05$ ), yang bermakna variabel kesepian berdistribusi dan sebaran normal.

Tabel 4 . Hasil Uji Linearitas Hubungan

\begin{tabular}{cccc}
\hline Variable & F & Signifikansi & Keterangan \\
\hline $\begin{array}{c}\text { Kecenderungan Narsistik } \\
\text { Kesepian }\end{array}$ & 33.352 & 0.000 & Linear \\
\hline
\end{tabular}

Bersumber pada tabel 2 maka dapat dinyatakan variabel kecenderungan narsistik dan kesepian mempunyai relasi linear. Hal ini diketahui dari angka $\mathrm{Sig}=0.000(\mathrm{p}<0,05)$, yang berarti kedua variabel hubungan yang linear.

Tabel 5. Korelasi antara prokrastinasi akademik dengan perilaku menyontek

\begin{tabular}{ccc}
\hline Variabel & Pearson Correlation & Sig $(\mathrm{p})$ \\
\hline $\begin{array}{c}\text { Kecenderungan Narsistik } \\
\text { Kesepian }\end{array}$ & -0.414 & 0.000 \\
\hline
\end{tabular}

Pada tabel 3 hasil penelitian menunjukkan koefisien korelasi Product Moment sebesar - 0.414 dengan Sig $=0.000$ ( $\mathrm{p}<0.05)$, yang bermakna jika semakin tinggi kesepian maka semakin rendah kecenderungan narsistik dan sebaliknya. Hasil yang diproleh senada dengan penelitian yang diteliti oleh Astianingsih Sungkur dan Ferdinand Sumatio (2017) menunjukkan adanya hubungan negatif antara kesepian dengan ciri-ciri narsistik.

Tabel 6.Sumbangan Efektif

\begin{tabular}{lcccc}
\hline Model & $\mathrm{R}$ & R Square & Adjusted R Square & Std. Error of the Estimate \\
\hline 1 & $.414^{\mathrm{a}}$ & .172 & .165 & 19.76095 \\
\hline
\end{tabular}

Kemudian peneliti menguji besarnya sumbangan efektif dan bisa disimpulkan penelitian ini memperoleh koefisien $\mathrm{R}^{2}=0.172$ yang dapat diartikan bahwa sumbangan 17.2 persen kecenderungan narsistik memberi pengaruh terhadap kesepian sedangkan selebihnya 87.9 persen dipengaruhi dari faktor lain, yaitu dukungan sosial, resiliensi, kepercayaan diri, efikasi diri, kebiasaan belajar, optimism masa depan, regulasi emosi, konformitas, dan adversity intelligence yang tidak diteliti oleh peneliti 


\section{Simpulan}

Berdasarkan hasil penelitian yang didapatkan Ada hubungan negatif antara kesepian dengan kecenderungan narsistik pada mahasiswi Universitas Prima Indonesia dengan kolerasi Product Moment $(\mathrm{r})$ sebesar $\mathrm{r}=0,414$ nilai $\mathrm{p}$ sebesar 0,000 ( $\mathrm{P} \& \mathrm{lt} ; 0,05)$, artinya semakin tinggi kadar kesepian yang dirasakan seseorang, maka perilaku narsistik semakin rendah, atau sebaliknya semakin rendah kadar kesepian yang dirasakan seseorang,maka perilaku narsistik semakin tinggi.

Hasil penelitian ini menunjukkan bahwa sumbangan efektif yang diberikan variabel kecenderunga narsistik terhadap variabel kesepian adalah sebesar17,2 persen selebihnya 87,9 persen dipengaruhi oleh factor lain yang tidak diteliti seperti dukungan sosial, resiliensi, kepercayaan diri, efikasi diri, kebiasaan belajar, optimism masa depan, regulasi emosi, konformitas dan adversity intelligence.

\section{Daftar Rujukan}

Astianingsih, S. 2017. Hubungan Antara Kesepian Dengan Tendensi Narsistik Pada Pelaku Selfie Di Media Sosial. Jurnal Psikologi Vol. 10 No. 3 November 2017, 139-141. Fakultas Psikologi Universitas Mercu Buana Yogyakarta. Diakses pada tanggal 2 November 2018 dari https://repository.unair.ac.id/84034/4/FKP.N.\%2041-19\%20Sab\%20h.pdf

Barlow, H., D \& Durand, M., V. 2007. Psikologi abnormal. Jakarta: Penerbit Pustaka belajar

Bruno, F., J. 2000. Congver Loneliness: melakukan kesepian. Alih bahasa: Sitanggang. A.R.H. Jakarta: PT. Gramedia Pustaka Utama

Dian, E., S. 2017. Hubungan Antara Kesepian Dan Kecenderungan Narsisistik Pada Pengguna Jejaring Sosial Media Instagram. Jurnal Psikologi Vol. 16 No. 2 Oktober 2017, 147-154. Fakultas Psikologi Universitas Kristen Satya Wacana Diakses pada tanggal 1 November 2018 dari https://ejournal.undip.ac.id/index.php/psikologi/article/view/12985

Emmons, R., A. 1995. Narcisme Theory And Meansurement. Journal At Personality An Sosial Psychologi 52 : 117 Vol.2, No.01. Niakses pada tangal 14November2018darihttps://www.researchgate.net/publication/315860313_Narcissism

Kartono, K. 2012. Pemimpin Dan Kepemimpinan. Jakarta : PT. Raja Grafindo Persada

Maulana, H \& Gumelar, G. 2013. Psikologi Komunikasi Dan Persuasi. Jakarta: Kademia

Novi, N., S. 2017. Dampak Kecenderungan Narsiscisme Terhadap Self Esteem Pada Pengguna Facebook Mahasiswa Pgsd Unp. Jurnal Dimensi Pendidikan Dan Pembelajaran Vol. 5 No. 1 Januari $2017 \mid 25$ Universitas Nusantara Pgri Kediri. Diakses pada tanggal 21 Nopember 2018 dari http:// journal.umpo.ac.id/index.php/dimensi/article/download/319/327+\&cd =2\&hl=id\&ct=clnk\&gl=id

Russel, L. 2011. The Accelerated Learning Fieldbook. Bandung: Nusamedia.

Santrock, J., W. 2003. Adolescence Perkembangan Remaja. Jakarta: Erlangga

Sugiyono. 2013. Metode Penelitian Kuantitatif Kualitatif dan R \& D. Bandung:Penerbit Alfabeta 